\title{
Die konsep 'Seun van God' in Grieks-Romeinse en Hellenisties-Semitiese literatuur
}

\author{
Andries van Aarde \\ Departement Nuwe-Testamentiese Wetenskap (Afd A) \\ Universiteit van Pretoria
}

\begin{abstract}
The notion 'Son of God' in Graeco-Roman and Hellenistic-Semitic literature

Christians among the Greek-speaking Israelites referred to Jesus as, inter alia, 'Son of God'. The connotation of this honorific title differs from the usage of that by Israelites prior to Hellenistic influence, who in the First Testament referred to their messianic king as 'Son of God'. The new connotation was, to a Hellenistic audience, a commonality. According to Rudolf Bultmann it was 'gemeingriechische Denke'. The article aims at identifying three different types of the notion 'Son of God' in Graeco-Roman and Hellenistic-Semitic literature: the divine human as miracle worker, the pre-existent God-like figure who is paradoxically associated with human fate, and the cosmological figure who is identified as God's Wisdom. It is shown that all three types occur in the Second Testament as interpretations of the soteriological meaning of Jesus' birth and death.
\end{abstract}

\section{INLEIDING}

In sy brief aan die Galasiërs (4:4-6) skryf Paulus:

Maar toe die tyd wat God daarvoor bepaal het, aangebreek het, het $\mathrm{Hy}$ sy Seun gestuur. Hy is uit 'n vrou gebore en van sy geboorte af was Hy aan die wet onderworpe om ons, wat aan die wet onderworpe was, los te koop sodat ons as kinders van God aangeneem kon word. En omdat ons sy kinders is, het God die Gees van sy Seun in ons harte gestuur, en in ons roep Hy uit: 'Abba!' Dit beteken: Vader!

(Nuwe Afrikaanse Vertaling, 1983; my beklemtoning)

Dieselfde gedagte word in Paulus se brief aan die Romeine (8:14-17) aangetref. Ook die Romeinebrief meld dat Christus Jesus die Seun van God is (kyk Rom 1:4), dat God 
die Heilige Gees aan gelowiges gegee het (kyk Rom 5:5), dat diegene wat deur die Gees van God gelei word, kinders van God is (kyk Rom 8:14) en dat hulle op grond van hulle pneumatiese bestaan as aangenome kinders van God, God as $A b b a$, wat Vader

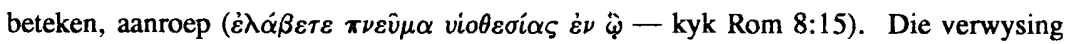
na God as 'Abba, Vader' (A $\beta \beta \alpha \dot{o}$ ж $\alpha \tau \dot{\eta} \rho)$ kom in die mond van Jesus self voor, soos berig in Markus 14:36. Matteus (26:39) bevat alleen die uitdrukking 'my Vader'

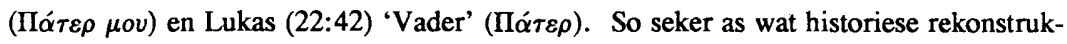
sie maar kan wees, kan aanvaar word dat die verwysing na God' as 'Vader' 'n ipssissimum verbum Jesu is (kyk o a Funk \& Hoover 1997:149).

Volgens my eie navorsing oor die historiese Jesus (kyk Van Aarde 1997a) is dit duidelik dat Jesus se aanroep van God as 'Vader' en 'Pappa' ('Abba') nie presies dieselfde konnotasies het as wat Paulus (kyk Van Aarde 1998) daarmee gehad het toe hy die Christene God só laat aanspreek het nie. Wat Jesus en Paulus wel in ooreenstemming het, is dat 'kinders van God' nie noodwendig biologies 'kinders van Abraham' is nie, soos dit konvensioneel deur die Israeliete gesien was. In 'n ander bydrae (Van Aarde 1997b) het ek aandag gegee aan Paulus se gebruik van die term 'aanneming tot kind' (viotzoí). Paulus gee met hierdie term uitdrukking aan die oortuiging dat gelowiges nie van nature 'kinders van God' is nie, maar op grond van hulle gebondenheid aan Jesus, die Seun van God.

In hierdie artikel wil ek enkele kanttekeninge skryf by die sosio-religieuse agtergronde van die gebruik van die benaming 'Seun van God' in Grieks-Romeinse en Hellenisties-Semitiese literatuur. Heeiwat navorsing is reeds hieroor gedoen (vgl o a Pokorny 1971; Hahn 1974:319-333; Hengel 1976). Wat myself betref, volg ek Rudolf Bultmann (1968:130-135) omdat hy oor hierdie tema baie duidelik formuleer en die agtergronde van hierdie konsep besonder sistematies uiteensit. Tussendeur my parafrase van Bultmann se uiteensetting vul ek inligting in wat uit my eie navorsing voortgespruit het. Die ander dele in die artikel is in geheel die produk van my eie selfstandige navorsing - navorsing wat my juis in staat gestel het om Bultmann se kompakte beskrywing beter te verstaan.

\section{KURIOS EN SEUN VAN GOD}

In Filippense 2:9-11 gebruik Paulus die Kurios-benaming om die kroon van Christus se verlossingswerk te beskryf: 'God het Hom ... die Naam gegee wat bo elke naam is, sodat in die naam van Jesus ... elke tong sou bely: "Jesus Christus is Kurios"'. Hiervolgens is dit duidelik dat die verhoogde Christus vir Paulus 'Kurios' is. In Afrikaans word hierdie benaming met Here vertaal. Eweneens is die benaming Seun 'n betiteling van die verhoogde Christus. So lees ons byvoorbeeeld in die Hebreërbrief (1:4) dat die 'mees voortreflike naam' ( $\delta \iota \alpha \phi \rho \omega \omega \epsilon \omega \varepsilon \rho o \nu$ ǒ $\nu \circ \mu \alpha)$ wat God aan die verhoogde Christus 
gegee het en wat Hom bó al die engele uitlig, die benaming 'Seun' is. Ook in die Herder van Hermas (Sim IX 14,5) verneem ons dat die 'noam Seun van God groot is en die hele wêreld onderhou'. Volgens Bultmann (1968:130) hoort beide name, 'Kurios' en 'Seun van God', bymekaar. Seun van God verwys na die Goddelike 'natuur' ('göttliche Wesen') van die Kurios wat as 'n kultiese figuur vereer word. Omgekeerd verwys Kurios na die status en die funksie ('Rang und die Funktion') van die figuur wat na sy wese Seun van God is.

Dit was in die Hellenistiese kerk dat die titel 'Kurios' vir die eerste keer aan Christus in verband met Goddelike natuur gegee is. Die Arameessprekende Christene in die vroegste kerk het Jesus reeds só - as vertaling van 'rabbi' ( $\dot{\rho} \alpha \beta \beta \iota / \delta \iota \delta \alpha \sigma \sigma \alpha \lambda{ }^{\circ} \varsigma$ ) na analogie van die gebruik in die tora-georiënteerde sinagogale kultus - genoem (vg1 Bultmann 1968:125; Sand 1974:164; Van Aarde 1994a:62). Dit was egter die Christene onder die Griekssprekende Israeliete wat as deel van hulle sendingboodskap die titel 'Seun van God' met hulle saamgebring het. 'n Mens moet onthou dat hierdie titel wat aanvanklik by die Israeliete na 'n messiaanse koning verwys het, nou in die kerk wat hoofsaaklik uit Griekssprekende Israeliete bestaan het, 'n nuwe betekenis gekry het. Hierdie nuwe konnotasie was vir die heidense hoorders 'n vanselfsprekendheid ('selbstverständlich' - Bultmann 1968:131). Op hierdie stadium van die geskiedenis van die kerk het die titel 'Seun van God' begin verwys na die Goddelikheid van Christus ('das göttliche Wesen Christi'), sy Goddelike natuur ('seine göttliche Natur' - Bultmann 1968:131). Op grond van sy Goddelikheid is Christus van die menslike sfeer onderskei.

\section{SEUN VAN GOD EN GODDELIKE OORSPRONG}

Met die titel 'Seun van God' is daar dus die aanspraak gemaak dat Christus van Goddelike oorsprong is en gevul is met Goddelike 'krag' ('göttlicher $\delta \dot{\nu} \nu \alpha \mu \varsigma^{\prime}$ ). Dat hierdie betekenis binne die Hellenisme vanselfsprekend aan die titel 'Seun van God' gegee is, is uit ' $n$ dubbele feit aanduibaar.

Die een deel daarvan is dat die verlossingsgebeure in die denkstruktuur van Hellenistiese Christene juis as 'n paradoks voorgestel word. Vir die vroegste kerk, dit is Christene ingebed in die Israelitiese tradisie, is dit 'n aanstoot dat Christus voorgestel kon word as onderworpe aan lyding ( $\chi \rho \iota \sigma \tau o ̀ \varsigma ~ \pi \alpha \theta \eta \tau o ́ \varsigma)$. Vir die Hellenistiese kerk was so 'n voorstelling nie 'n struikelblok ( $\sigma \alpha \alpha \dot{\nu} \delta \alpha \lambda o \nu)$ nie, maar wel 'n 'misterie' ( $\mu v \sigma \tau \dot{j} \rho \iota \nu$ - Bultmann 1968:131). Hierdie paradoksale misterie bestaan daaruit dat 'n figuur, Goddelik in wese, in die vorm van 'n mens verskyn en die lydenslot van 'n mens ervaar. Getuienis van so 'n verskyning en ervaring kan byvoorbeeld gesien word in die Christus-himne wat deur Paulus in Filippense 2:6-11 aangehaal is. 
Die ander deel van die dubbele feit is die problematiek rondom die voorstelling van die menslikheid van die Seun van God ('Menschheit des Gottessohnes' - Bultmann 1968:131). Die egtheid van Christus se menslikheid moes teenoor die Gnostiese kettery verdedig word ter wille van die gemelde paradoks van die verlossingsgebeure ('Paradoxie des Heilsgeschehens' - Bultmann 1968:131). Die essensie grondliggend aan die gebruik van die term 'Seun van God' in die Hellenistiese kerk was om op die Goddelikheid van Christus te wys. Dit kom daarom nie as 'n verrassing nie dat 2 Klemens (1:1) met die woorde begin: 'Ons behoort oor Jesus Christus te dink soos ons

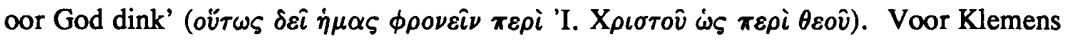
het die skrywer van die Hebreërbrief, soos ons vroeër daarop gewys het, reeds geleer dat Christus bó die engele verhoog is. Die Hebreërbrief (1:3) beskryf Christus as die

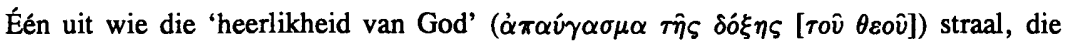

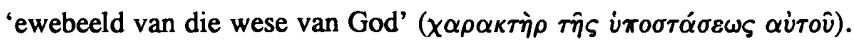

Tog het die Nuwe Testament oor die algemeen gesien ernstige voorbehoud om Christus 'God' te noem (kyk ook o a Bultmann 1952:248; Richardson 1979; Harris 1992). Buiten Johannes 1:1, waar die preëksistente Logos 'God' genoem word, en Johannes 20:28, waar Tomas die opgestane Christus vereer met die uitroep, 'My Here en my God', word die aanname 'Christus is God' - ten minste op grond van wat na alle waarskynlikheid eksegeties van hierdie tekste gesê kan word - alleen in 2 Tessalonisense 1:12, Titus 2:13 en 2 Petrus 1:1 gemaak. [Die doksologie in Rom 9:5 kan nouliks op Christus betrek word en die lesings in Joh 1:18 en 1 Tim 3:16 is, tekskrities gesien, sekondêr - Bultmann 1968:131 nota 1.] Hierteenoor praat die tweede-eeuse Ignatius (Ad Trallianos 7:1; Ad Smyrnaeos 1:1; 10:1) van Christus as God asof so 'n spreke heel vanselfsprekend is. Gewoonlik sê Ignatius (Ad Ephesios [proloog]; 15:3; 18:2; Ad Romanos [2x in proloog]; 3:3; Ad Polycarpum 8:3): '(Jesus Christus) ons God'. Wat vir Ignatius belangrik was, was juis om te wys op die paradoks wat uit-

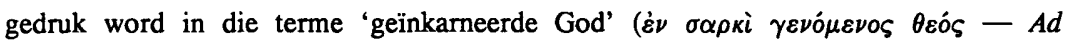

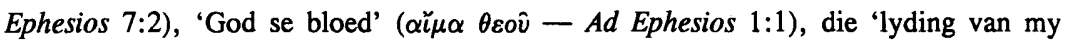
God' ( $\pi \dot{\alpha} \theta 0 \varsigma$ rov̂ $\theta \varepsilon o \hat{v}$ pou - Ad Romanos 6:3) of die 'brood van God, dit is die 'vlees'

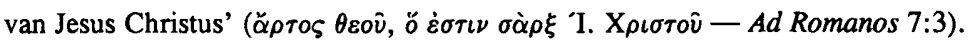

'n Mens behoort jou nie daaroor te verwonder dat die verkondiging van 'Christus, die Seun van God' op hierdie wyse verstaan is nie, want ons moet onthou dat die Hellenistiese denkstruktuur vertroud was met die figuur van 'n seun van God, en wel in verskillende vorme. Bultmann (1968:132) praat van gemeingriechische Denke. Een vorm hiervan is 'n erfenis vanuit die Griekse tradisie wat gebruik gemaak het van die mitologiese idee van die verwekking van ' $n$ kind op grond van die seksuele gemeenskap van 'n godheid met 'n sterflike mens. Mense wat só gebore is, se lewe word geken- 
merk deur hulle heldedade en geestelike bydraes ('geistliche Leistungen' - Bultmann 1968:132) tot die mensheid - weldade wat gewone menslike maatstawwe ver te bowe gaan. 'n Hele reeks van sulke 'god-mense' ( $\theta \varepsilon i \hat{\imath} \iota \check{\alpha} \nu \delta \rho \varepsilon \varsigma)$ vanuit die Hellenistiese periode is bekend. Hierdie 'god-mense' het aanspraak daarop gemaak om 'seuns van (' $n$ ) god' (vioi $\theta \varepsilon o v$ ) te wees en sommige van hulle is ook kulties vereer. In die geval van hierdie 'god-mense' is daar geen, of bykans geen, beklemtoning van die paradoks van die goddelike wat in menslike vorm verskyn nie. Daar was buitendien hoegenaamd geen probleem oor die algemeen gesien met die beskouing in die Griekse denke dat die siel van elke mens ' $n$ 'goddelike entiteit' is nie. In werke van Epictetus, Marcus Aurelius en Plotinus verneem ons dat diegene wat geag was as mense met verstand ( $\nu$ ov̂), beskou was as mense met 'n 'god in hulle' (kyk Harris 1992:28 nota 38). In die Griekse denke is die interesse nie in die (paradoksale) feit van 'n goddelike seun se menslikheid nie, maar in die inhoud van sy lewe (Bios) wat gekenmerk word deur charismatiese verskynsels en wonderwerke (Bultmann 1968:132).

'n Ander voorstelling was die konsep van wat in die oosterse Hellenisme algemeen bekend was en wat vanuit die erfenis van die oud-Oosterse mitologie kom. Dit is naamlik die idee van seun-gode ('Sohnesgottheiten' - Bultmann 1968:132). Hierdie gode was kulties vereer deurdat hulle in die vorm van 'misteries' aanbid is. Hulle was geag as verlossersfigure. Die mites oor hierdie gode vertel hoe hulle die menslike lot van dood gely het, maar dat hulle weer vanuit die dood opgestaan het. Volgens die oortuigings van hulle aanbidders het die lot van hierdie gode ' $n$ verlossing bewerkstellig waaraan die aanbidders deelkry as hulle die godheid se dood en opstanding in die vorm van die rites van die misteries ervaar. Die oorsprong van hierdie goddelike figure lê in die antieke vrugbaarheidsgodsdienste. Verwant aan dié 'misteries' is die figuur van die verlosser in die Gnostiese mite. Sekere van die Christene afkomstig vanuit die heidenwêreld het die soteriologiese betekenis van Jesus se geboorte en dood vir hulle verstaanbaar gemaak met behulp van beide die konsepte goddelike seunskap en die gnostiese verlossersfiguur wat van bo kom. So lees ons byvoorbeeld dat die skrywer(s) van die Johannesevangelie oor Jesus sê: 'Só is God se liefde vir die kosmos: Hy het sy

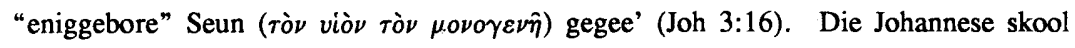
laat vir Jesus self op die vooraand van sy dood sê: 'Ek is hiervoor gebore ( $\gamma \varepsilon \gamma \varepsilon \dot{\varepsilon} \nu \eta \mu \alpha \iota)$ en het hiervoor die kosmos ingekom' (Joh 18:37). In 1 Johannes 3:16 lees ons: 'Hieráán weet ons wat liefde is: Daardie man [Jesus Christus, die Seun van God - 1 Joh 3:

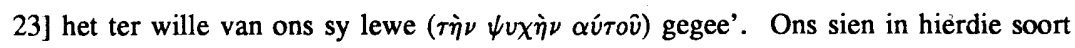
uitsprake dat die paradoksale konsep van 'n goddelike wese ('n 'seun-godheid') wat mens word en 'n menslike lot ly, verbind word met die gnostiese idee van 'n verlosser wat van bo in die kosmos hieronder inkom. 
Die voorstelling van Christus as Seun van God wissel in 'heiden-Christelike' kringe na gelang van watter tradisie, die mitologiese 'seun-god' of die mitologiesgnostiese, hierdie voorstelling die meeste beïnvloed het.

\section{SEUN VAN GOD EN DIE KONSEP 'GOD-MENS'}

Die sinoptiese evangelies verteenwoordig in essensie die eerste tipe in so verre dit uitbeelding is van Jesus as die Seun van God wat sy Goddelike gesag ('göttliche $\dot{\varepsilon} \xi o v \sigma i \alpha$ ' - Bultmann 1968:133) deur sy wonderwerke openbaar (vgl Betz 1968:114-133; Koester 1971:158-204). Dit is 'n voorstellingswyse wat gepas het in daardie Christelike denke wat deur Israelitiese beskouings bepaal is. Binne hierdie denkraamwerk is die 'krag' wat in die lewe van die 'God-mens' manifesteer, toegeskryf aan die Goddelike Gees wat die 'God-mens' vervul het. Dit was 'n verskynsel wat volgens Hellenistiese interpretasie ook in die lewe van Ou-Testamentiese 'Godsmanne', soos Dawid en die profete, aanwesig was. Hierdie 'Godsmanne' het vir Christene wie se denke beïnvloed is deur hoofsaaklik die Israeltiese denkstruktuur, as analogie gedien ten opsigte van hulle belydenis dat die Christus die Seun van God is. Bultmann (1968:133) meen dat dit teen hierdie agtergrond is dat die storie oor Christus in die Markusevangelie vertel is (kyk ook Weeden 1971). Volgens Markus (1:9-11) manifesteer Jesus as Seun van God toe Hy by geleentheid van sy doop deur die Gees van God vervul is. Bultmann (1968:133) wys daarop dat hierdie selfde siening duidelik na vore kom in die 'westelike' manuskriptradisie van Lukas 3:22 tot en met Augustinus (onder andere die Latynse versie van die vyfde-eeuse kodeks Bezae Cantabrigiensis [ $D^{i t}$ ], Justinus, Klemens en Latynse dokumente van 'n hele aantal westerse kerkvaders - kyk Aland et al 1994: 207). Hiervolgens het die stem vanuit die hemel in die woorde van Psalm 2:7 gesê: 'Jy

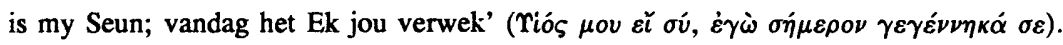
In lyn met hierdie denkwyse vertel Handelinge 2:22: 'God het Jesus van Nasaret aan julle bekend gestel ( $\dot{\alpha} \pi \circ \delta \varepsilon \delta \varepsilon เ \gamma \mu \varepsilon ́ \nu 0 \nu \alpha \pi \grave{~} \tau o \hat{v} \theta \varepsilon o \hat{v}$ ) deur kragtige dade, die wonders en die tekens wat God Hom by julle laat doen het' (NAV).

Maar dit is ook ' $n$ feit dat die mitologiese idee van 'n goddelike seun wat deur een of ander godheid verwek is, in Egipte deur die Hellenisme in die Israelitiese tradisie oorgeneem is en van toepassing gemaak is op die 'heilige mense' ('die Frommen' Bultmann 1968:133) van die Ou Testament. Hierdie mitologiese idee, weet ons, was nie net aan die Griekse tradisie bekend nie. Dit was 'n algemene opvatting binne die konteks van die Babiloniese en veral die Egiptiese 'koning-legende' (kyk Widengren 1969:360-369). Gesien die bekendheid van hierdie idee in Hellenistiese Egipte is dit derhalwe geen verrassing nie dat die legende oor die maagdelike geboorte vroeg in die 
periode van die Hellenistiese Christendom vorendag gekom het. Volgens Matteus se weergawe van hierdie legende is Jesus op grond van die intervensie van die 'Gees [van

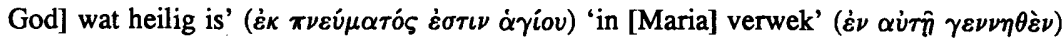
(Matt 1:20). Volgens Lukas is Jesus 'verwek' op grond van die 'Heilige Gees'

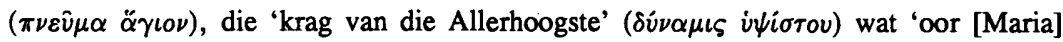

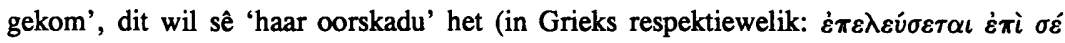
en $\dot{\varepsilon} \pi \iota \sigma \kappa \iota \dot{\alpha} \sigma \varepsilon \iota \sigma o \iota$ - Luk 1:35).

Hoewel ek soos Bultmann (1968:133) die woord verwek ('erzeugen') by beide die Matteus- en Lukas-weergawes van die Jesus-geboortetradisie gebruik, is dit opvallend dat Matteus, ten spyte van die die gebruik van die Griekse woord $\gamma \varepsilon \nu \nu \alpha ́ \omega$ in Matteus 1: 20, nie iets sê oor hoe Maria geboorte gegee het of oor die wyse waarop Jesus verwek is nie (vgl Van Aarde 1994a:272). Ek stem daarom met Raymond Brown (1979:124) saam: 'There is never a suggestion in Matthew ... that the Holy Spirit is the male element in a union with Mary, supplying the husband's role in begetting'. Die ontbrekende deel in hierdie aanhaling lui: 'or in Luke'. Hier verskil ek egter van hom (kyk Brown 1979:290 se toegewing egter met betrekking tot Matteus). Wat Lukas betref, het ons volgens Brown (1979:290-291, 327-328) te doen met Ou-Testamentiese parallelle in verband met enersyds die teenwoordigheid van God in die lewe van Israel en nou in die lewe van die 'maagd Maria' wat met die uitdrukking 'tabernakelagtige

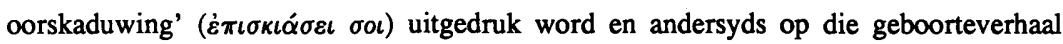
met betrekking tot die 'nederige vrou' Hanna, soos dit veral in die 'lied van Maria', die Magnificat (Luk 1:46-55), uitgedruk word. Met die opmerking oor die Maria-Hanna parallel stem ek saam, maar nie oor dié rakende die betekenis van die uitdrukkings 'oor

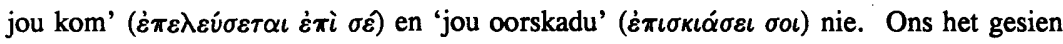
dat Brown (1979:124), soos Dibelius (1932:19-27), nie meen dat hierdie uitdrukkings enige seksuele konnotasies bevat nie. Daar is egter eksegete (kyk Daube 1957:119120) wat oordeel dat ons hier te doen het met ' $n$ toespeling op die idiomatiese uitdrukking in Rut 3:9, 'sy borok/kombers oor haar sprei'.

In Rut 3:9 lees ons dat Rut haarself as diensmeisie aan Boas gebied het, sodat 'hy

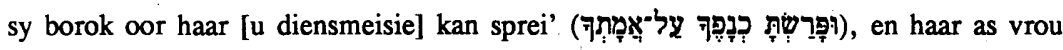
kan vat. In die Rabbynse debat oor Rut 3:9 word Rut (en Naomi wat agter die plan sit) se doelbewuste verleiding van Boas weggeredeneer deurdat die woord 'borok' (oftewel

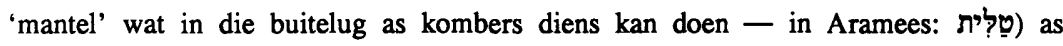
'oorskadu' gelees word (in Aramees: טֵלֵ (kyk Daube 1957:119-120). Ook in die Septuaginta vind ons die uitdrukking 'vlerke/vleuels oor haar sprei' (Rut [LXX] 3:9 -

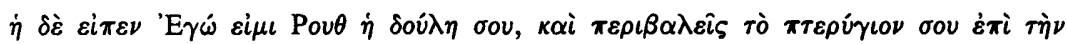

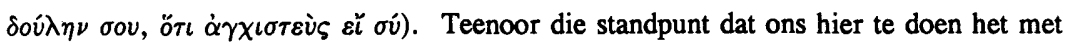


'n sinspeling op seksuele gemeenskap, meen ander kommentatore dat hier eerder sprake is van ' $n$ versoek van Rut dat Boas met haar sal trou en dat die idioom 'vleuels oor haar sprei' betrekking het op beskerming (De Waard \& Nida 1973:54).

Die woord 'vlerke/vleuels' ( Lukas 4:9 en Matteus 4:5 voor. Daar het dit vermoedelik betrekking op die 'hoogste punt van die tempel'. Eintlik weet ons nie werklik waarna die betrokke woord (tò

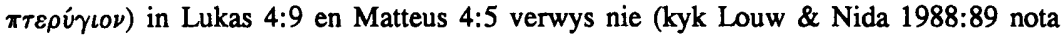

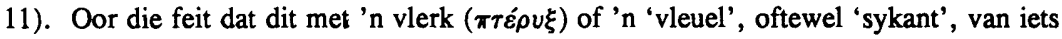
te doen het, bestaan daar nie twyfel nie (kyk Lidell \& Scott [1940] 1961:1547). Wat ook al die geval is, in Rut 3:9 het ons met ' $n$ metafoor te doen. En of dit die man se borok/mantel is wat oor die vrou uitgesprei word en of dit die man is wat by wyse van spreke sy vleuels oor die vrou uitsprei, die konnotasie op seksuele gemeenskap kan myns insiens nie weggeredeneer word nie. In die Griekse vertaling van Deuteronomium 22:30 (MS - 23:1) en in Deuteronomium 27:20 kom dieselfde idioom met betrekking tot die man se mantel/kombers voor, hoewel ander leksikaliese terme gebruik is, en daar verwys dit ongetwyfeld na seksuele gemeenskap (kyk ook Smith 1903:105).

Afgesien van die betrokke idioom is dit in die Grieks-Israelitiese tradisie nie vreemd om in mitologiese sin te verneem van 'Goddelike wesens', soos engele, wat 'sterflike vrouens' bevrug nie (kyk 1 Henog 6-7; Genesis Apocryphon 2, [1QapGen]; Testament van Salomo [Test Sal] 5:3; Proto-evangelie van Jakobus [Prot Jak] 14:1) (vgl o a Allison 1993:147 nota 14). In die Wysheid van Salomo (8:16-18) is daar sprake van 'n erotiese liefdesverhouding tussen die preëksistente, gepersonifieerde Sofia ('Wysheid') en die 'wyse mens': '(Always when) I am coming home I shall sleep with her [LXX: $\pi \rho \circ \sigma \alpha \nu \alpha \pi \alpha \dot{v} \sigma o \mu \alpha \iota \alpha \dot{v} \tau \hat{n}$ - Rahlfs 1971:357], for intercourse with her [i்

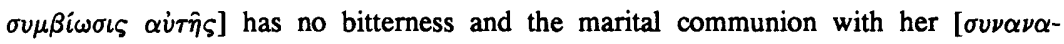
$\sigma \tau \rho \circ \phi \grave{\eta}]$ no hurt, but joy and merriment' (Standhartinger 1996:309; vertaling deur Dieter Georgi). In Josef en Aseneth [JosAs(Ph)] 15:7-8, die sogenoemde korter gekonstrueerde versie van Marc Philonenko (1968), geskryf in die periode tussen 100 v C en 115 n C (Chesnutt 1996:286), word Sofia met die figuur Metanoia (verwysende na Aseneth) vervang: 'And Metanoia is a virgin, very beautiful and pure and chaste and gentle; and God Most High loves her, and all his angels do her reverence ( $\alpha i \delta \varepsilon \hat{\imath} \sigma \theta \alpha \iota$ )' (Standhartinger 1996:309). In Christoph Burchard (1965) se langer gekonstrueerde versie lees JosAs 17:9(B): '(What a) foolish ( $\alpha \phi \rho \omega \nu)$ and bold ( $\tau 0 \lambda \mu \eta \rho \alpha$ ) (woman) I (am), because I have spoken with frankness ( $\pi \alpha \rho \rho \eta \sigma i \alpha)$ and said that a man came into my chamber from heaven; and I did not know that (a) god came to me' (Standhartinger 1996:311). 
Myns insiens is Esegiël 16:6-9 in hierdie verband 'n belangrike Ou-Testamentiese parallel. Hier word onteenseglik in die mitologiese sin van die woord en by wyse van analogiese spreke verwys na Jahwe wat met 'n maagd, verwysende na Israel, gemeenskap het. Wevers (1969:121) vertaal Esegiël 16:7-9 soos volg: 'And you grew up and became tall and arrived at full maidenhood; your breasts were formed, and your hair had grown; yet you were naked and bare. When I passed by you again and looked

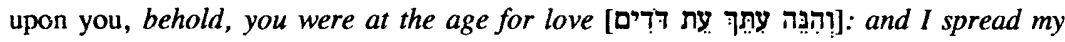

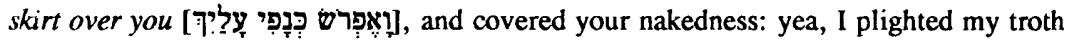
to you and entered into a covenant with you, says the Lord God, and you became mine. Then I bathed you with water and washed off your blood from you, and anointed you with oil' (my beklemtoning). Die uitdrukking wat in die Griekse vertaling van Esegiël 16:8 (kyk Rahlfs 1935:792) gebruik word, is: 'vleuels oor haar uitsprei' ( $\delta \iota \varepsilon \pi \varepsilon \tilde{\varepsilon} \alpha \sigma \alpha$ $\tau \grave{\alpha} \varsigma \pi \tau \dot{\varepsilon} \rho v \gamma \dot{\alpha} \varsigma \mu o v \dot{\varepsilon} \pi \grave{\imath} \sigma \grave{\varepsilon})$. Hierdie parallel is vir ons doeleindes belangrik omdat die konteks van Esegiël 16 betrekking het op Jahwe wat 'n weggegooide dogtertjie, so pas gebore op grond van 'n illegitieme verhouding buite die aanvaarbare huweliksmaatreëls wat binne die priesterlike Israelietiese verbondsgemeenskap gegeld het (kyk Eseg 16:3), aangeneem het (kyk Eichrodt 1970:204-205).

In die Rut-tradisie kry ons ook die motief van aanneming tot kind van God, 'n aanneming tot deelhê aan die verbondsvolk. Dieselfde motief, gepaardgaande met die analogiese spreke met betrekking tot 'n Goddelike verwekking, soos betuig in Esegiël . 16, word aangetref in die Jesus-geboortetradisie wat gemeenskaplik aan Lukas en Matteus" is. Brown (1979:290) sê egter hy weet nie hoe Lukas (en Matteus) hierdie (Rut-) tradisie as parallelle motief in die oog kon gehad het nie. Hierop kan 'n mens reageer deur daarop te wys dat beide die Matteus- en Lukas-geboortevertellings duidelik die motief bevat dat Jesus op grond van Goddelike intervensie tot kind van die verbondsgemeenskap aangeneem is. Beide evangeliste se geboorterekords van Jesus weerspieël besliste kennis van die betrokke Rut-tradisie: 'die seun van Obed, die seun van Boas' (Luk 3:32); 'Boas die vader van Obed by Rut' (Matt 1:5). Verder kan ook verwys word na die vervullingssitaat in die kindheidsvertelling in Matteus 2:18. Hier het ons ' $n$ direkte toespeling op die plekke Efrata en Betlehem na aanleiding van die Ragel-tradisie in Jeremia 31:15.

Ek het elders betoog dat Matteus waarskynlik nie die maagdskap van Maria as sodanig in die oog gehad het toe hy Jesaja 7:14 aangehaal het nie (kyk Van Aarde 1996a:495). Wat Matteus 1:23 (kyk ook Matt 28:20) in die oog het, is eerder die 'Immanuel'-motief wat in Jesaja 7:14 voorkom en ' $n$ toespeling is op die motief van die 'koningskind' wat in Jesaja 8:8 genoem word: 'God met ons' (LXX - $\mu \varepsilon \theta$ ' $\dot{\eta} \mu \hat{\omega} \nu$ $\theta \varepsilon o ́ \varsigma)$. Hier moet 'n mens waak teen anakronistiese eksegese. 'n Voorbeeld hiervan is 


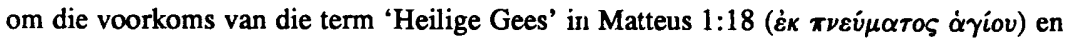

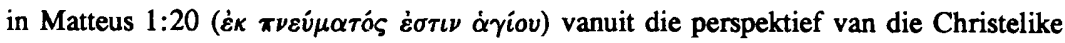
dogma oor die Triniteit te interpreteer. So 'n interpretasie word gedurende die Middeleeue by onder andere Thomas Aquinas (kyk Van Aarde 1996a:496) en later in die edik van pous Paulus IV in 1555 teen die antitrinitariërs en die Sociniane (kyk Koekemoer 1958:190-191), aangetref. Hierdie mense het geleer: '... ons Heer (is) nie ware God ..., in alle opsigte van dieselfde wese soos die Vader en die Heilige Gees nie, of dat Hy volgens die vlees nie ontvang is van die Heilige Gees in die skoot van die allersaligste en altyd maagdelike Maria nie [aut eundem secundum carnem non esse conceptum in utero beatissimae semperque Virginitas Mariae de Spiritu Sancto], maar soos die ander mense uit die saad van Josef [sed sicut ceteros homines ex semine Joseph]' (in Koekemoer 1958:190-191). Sonder om sy opponente toe te gee, moet daarop gelet word dat pous Paulus IV se afwysing van die antitrinitariërs eintlik die Rooms-Katolieke Mariologie in verband met die ineengevlegte dogmas van die 'onbeviekte ontvangenis' en die 'altyd maagdelike Maria' verdedig.

Om anakronisme in ons verstaan van Matteus se interpretasie van Jesus se aanneming tot 'kind van Josef', op grond van die intervensie van die Heilige Gees, te voorkom moet daar gelet word op onder andere die oortuigings wat daar bestaan in kontemporêre tekste oor 'Josef, die seun van Jakob'. In die pseudepigrafiese geskrif, Testamente van die Twaalf Patriarge, gedateer (wat die huidige vorm betref) in die tweede of derde eeu $\mathrm{n} \mathrm{C}$, maar waarvan materiaal teruggaan tot moontlik die tweede eeu $\vee \mathrm{C}$, is daar byvoorbeeld ' $n$ tradisie dat die Bybelse figuur Josef, die seun van Jakob, nie net die onskuldige slagoffer van die nydige en jaloerse 'bose oog' was nie, maar inderdaad die suksesvolle oorwinnaar van dié bose geeste (Testament van Simeon [T.Sim.] 1-2; Testament van Dan [T.Dan] 1:6; 2:5; Testament van Gad [T.Gad] 1-3; Testament van Josef [T.Jos.] 1:3, 7; Testament van Benjamin [T.Ben.] 3-6 - kyk Elliott 1994:68-69).

Teen hierdie agtergrond was rabbi's van die sogenoemde Jamnia Akademie, allerweë beskou as die opponente van die Jesus-beweging waarteen onder andere die evangelis Matteus die Godseunskap van Jesus verdedig (kyk o a Overman 1990:35-71; Stanton 1992:113-281; Saldarini 1994:167-177; Van Aarde 1994a:xiii-xvii; 248-260), van oortuiging dat hierdie beskerming wat Josef teen die bose geeste geniet het, ook vir die nageslag van Josef geld (kyk Elliott 1994:73 nota 26). In die Talmud (b.Bava Mezia 84a; vgl Berakot 20a) word 'n tradisie in hierdie verband oor een van die leiers van die Jamnia Akademie aangetref waarin hy homself sien as van die 'saad van Josef' en daarom het die 'bose oog' nie mag oor hom nie (kyk Elliott 1994:73 nota 26).

Die Heilige Gees is in die Israelitiese denkwêreld die krag wat die bose oorweldig. Getuienis hiervan kom etlike male in die Matteusevangelie voor (bv Matt 12:28). In hierdie selfde evangelie is daar ook die woordspel rakende opponerende benamings: 
'seun(s) van God' versus 'seun(s) van die bose' (kyk Van Aarde 1994a:69-71). Soos Jesus, as die aangenome 'seun van Josef' en 'Seun van God', is die dissipels volgens Matteus veronderstel om as 'seuns van God' mag oor die 'bose' en die 'seuns van die bose' te hê (o a Matt 10:20, 24-26 - vgl Van Aarde 1994a:77). Dit is van betekenis dat Derrett (1973:123) in die konteks waarin hy dit het oor die geloof in die 'bose oog' in die Mediterreense sosiale wêreld, die volgende opmerking oor Israeliete se opvatting oor geboortes in die algemeen maak: 'The Hebrews viewed childbirth as symbolic of destiny in a most intimate way. No conception took place without the co-operation of the holy spirit' (Derrett 1973:119; my beklemtoning).

Dit is duidelik dat daar parallelle bestaan tussen Matteus se verstaan van Jesus as 'Seun van Josef', 'Seun van Abraham' en 'Seun van God' en voorstellings in die Grieks-Israelitiese en Rabbynse wêreld, insluitende literatuur soos Wysheid van Salomo en Josef en Aseneth. Hierdie parallelle getuig nie noodwendig van direkte bronneafhanklikheid nie. Dit is eerder 'n kwessie van gemeenskaplike denke. Nadat Saldarini (1994:167-177) kommentaar gelewer het op die parallelle wat daar in die Jesus-geboortetradisie en in res van die Evangelie van Matteus bestaan, maak hy die volgende opmerking: 'The author of Matthew drew upon this rich and varied tradition when he stressed God the Father of Jesus in the birth narrative (chap.1). At the same time, he brought a variety of titles, roles, and scriptural passages to bear on Jesus in order to establish him firmly within the biblical world and further mark him out as a special figure in Israel ...' (Saldarini 1994:176).

Indien die woordjie 'maagd' ( $\pi \alpha \rho \theta \dot{\varepsilon} \nu \circ \varsigma)$ in die betrokke aanhaling van Jesaja 7:14 deur Matteus wel intensioneel sou gewees het, het ek reeds vroeër geredeneer (Van Aarde 1996a:495), sou Matteus heel waarskynlik die Goddelike verwekkings in tradisies soos dié in die haggadiese Moses-paasgeskrif (b.Baba Batra 120a) en in die Midrash Rabbah (Eks Rab 1:19) oor Jogebed, die ma van Moses, in gedagte gehad het (vgl ook Allison 1993:147-155). In hierdie tradisie is Jogebed se 'maagdelikheid' deur God herstel voordat sy sonder die toedoen van Amram, haar man, geboorte aan Moses geskenk het.

Wat Lukas se weergawe van die geboorte van Christus betref, het ek die moontlike invloed van die Griekse mitologie op Lukas se vertelling van 'n maagdelike verwekking erken, maar gesê dat die detail van hierdie beïnvloeding nie aan my bekend was nie (kyk Van Aarde 1995:344). Navorsing het my gebring by die oortuiging dat geleerdes soos Bultmann (1968:133), Schmithals (1980:25-28) en Crossan (1994:72-76) die duidelikste verklarings bied deur die geboortevertelling van Christus in die Lukasevangelie uit te lê teen die agtergrond van die godeseun-mites in die kontemporêre Grieks-Romeinse literatuur. Die feit dat die legende in verband met die maagdelike verwekking vir Paulus onbekend was, bewys uiteraard nie dat dit nie 'n 
gangbare opvatting in die nie-Pauliniese Christelike kringe, selfs voóór Paulus se tyd, was nie (Bultmann 1968:133). In nie-Christelike kringe het die parallelle met betrekking tot die konsep van 'n maagdelike verwekking wyd voorgekom (kyk Brown 1979: 522): byvoorbeeld die verwekkings van Perseus en Romulus in die Grieks-Romeinse mitologie asook dié van die Farao's, Aleksander en Augustus in legendariese materiaal vanuit enersyds die Egiptiese en Grieks-Romeinse geskiedenis en andersyds dié van beroemde filosowe en godsdienstige denkers soos Plato en Apollonius van Tyana.

Tradisies oor 'n regeerder wat as 'n 'god' (in Grieks: $\theta \varepsilon o ́ \varsigma$, of in Latyn: deus) geag is, moet in hierdie verband ook vermeld word (kyk Harris 1992:26). Op die Rosettasteen, 196 v C, word van Ptolemeus V Epifanes berig dat hy "'n god uit 'n god en 'n

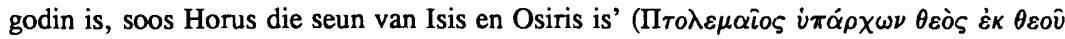

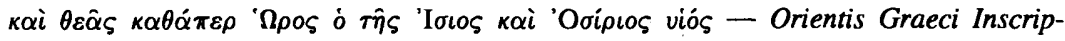
tiones Selectae 90:10). Vanuit Efese kom 'n inskripsie, gedateer 48 v C (kyk Dittenberger 1960:760.7), wat meld dat Julius Caesar 'die manifestasie van 'n god is, gebore uit Ares en Afrodite en (die) algemene verlosser van menslike lewe' (Tò $\dot{\alpha} \pi \grave{\text { } \mathrm{A} \rho \varepsilon \omega \varsigma}$

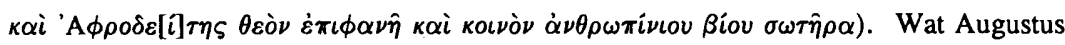
betref, is verskeie inskripsies bekend wat na hom as 'n god verwys. Vanuit Egipte kom die Oxyrhynchus Papirus (1453.11), gedateer 24 v C, wat na Agustus verwys as

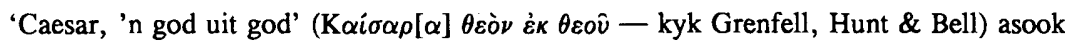
'n ander inskripsie, gedateer $24 \times \mathrm{C}$, met dieselfde verwysing, te wete 'god uit god' ( $\theta \varepsilon o \hat{u}$ غ̇ $\theta \varepsilon o \hat{v}$ - Orientis Graeci Inscriptiones Selectae 655.2). Ook die skrywer Strabo (Geographica 4.177 - vgl ook Taylor 1981:142-246, 270-283) verwys êrens in die periode voor sy dood in $21 \mathrm{n} \mathrm{C}$ (Berkowitz \& Squitier 1986:xix) na Augustus as

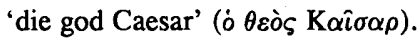

Die Nuwe Testament (Hand 12:22) ken ook 'n tradisie dat Herodes Agrippa I 'n god genoem is - 'n tradisie waarmee Josefus (Antiquitates 19.345) ook bekend was. Soortgelyke tradisies bestaan ten opsigte van die Romeinse keisers Nero en Domitianus (Harris 1992:28 notas 34 en 35). Wat Nero betref, vermeld Deißmann ([1927] 1965:345 nota 4) die inskripsie van Gaius Stertinus Xenophon van Kos waarin hy die keiser aanspreek as '(aan) die goeie god' ('A $\gamma \alpha \theta \hat{\varphi} \theta \varepsilon \hat{\varphi})$ ). Suetonius (De Vita Caesarum:

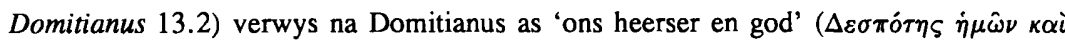
$\theta \varepsilon o ́ \varsigma)$. Soortgelyke verwysings na Domitianus word aangetref in die werke van Dio Chrysostomus (Orationes: Defensio 45.1) en Dio Cassius (67.4.7), geskryf in die periode tussen die einde-eerste eeu tot die begin-derde eeu n C (Harris 1992:28 nota 35). 
'n Mens kan daarom nie anders as om met Brown (1979:522-523) saam te stem dat dit nie denkbaar is dat bekeerlinge vanuit die heidendom tot die Christendom nie van hierdie parallelle uit Egipte, Griekeland en Latinum bewus sou gewees het nie. Myns insiens moet 'n mens nie net Lukas en Paulus (Gal 4:4; Rom 1:3; Flp 2:7) hieronder insluit nie maar, benewens Matteus, ook Markus (6:3) en die skrywers in die Johannese skool (Joh 1:13; 7:41-42; 1 Joh 5:18). Sketse en afbeeldings van voorstellings van figure met 'n goddelike geboorte en/of maagdelike verwekking soos onder andere Hercules, Perseus, Horus (die Isis-kultus) en Priapus, wat gevind is in huise in die stede Herculanum en Pompeii en omliggende dorpies, beskadig deur ' $n$ aardbewing in $62 \mathrm{n} \mathrm{C}$ en deur lawa toegeval in $79 \mathrm{n} \mathrm{C}$ as gevolg van die vulkaniese uitbarsting van die Vesuviusberg, is 'n duidelike aanduiding van die algemene bekendheid van sulke voorstellings (kyk Maulucci 1996:86-87; 106-107; 115; Bonechi (Casa Editrice) 1995:48, 98-100). Dit is daarom opvallend dat die opvatting ten opsigte van Jesus se Goddelike geboorte, buiten Matteus 1 en Lukas 1, nie elders in die Nuwe Testament voorkom nie.

Die woorde in Galasiërs $4: 4$, 'toe die volheid van die tyd gekom het, het God sy

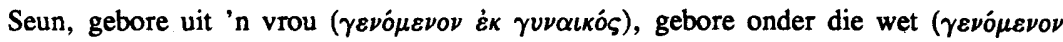

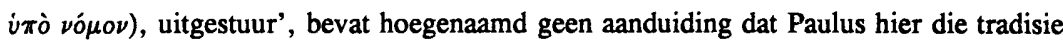
oor Jesus se maagdelike verwekking in gedagte gehad het nie (vgl Brown 1979:519). Tog kan ons myns insiens nie die afleiding maak dat Paulus hier niks sê oor hoe Jesus verwek is nie (vgl Dibelius 1932:29-34; contra Brown 1973:57). Volgens Paulus het Jesus, wat van huis uit die preëksistente Seun van God is en derhalwe van 'n gans ander orde as dié van mense, in alle opsigte gelyk geword aan die mense. Dit sluit sowel die aard van mense se geboorte in as die aard van die menslike geskiedenis en toestand (Oepke 1973:132-133; vgl ook Schlier 1971 a:196; Byrne 1979:181). Paulus dink nie aan Jesus se geboorte anders as in die terme van enige ander natuurlike geboorte nie. Dibelius (1932:34) formuleer dit soos volg:

Paulus spricht nirgends von der wunderbaren Geburt Jesu und zeigt deutlich die völlig entgegengesetzte Richtung seines Interesses: er legt entscheidenden Wert darauf, daß das Erdensein des Christus begonnen hat wie das eines anderen Menschen, durch eine näturliche Geburt.

Die uitdrukking wat Paulus gebruik, 'gebore uit 'n vrou' ( kom ook voor in Job 14:14 en Matteus 11:11, en daar het dit betrekking op 'n natuur-

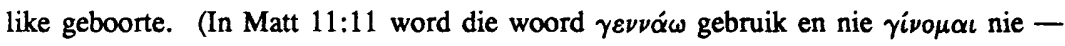
beide woorde kan 'om gebore te word' beteken.) Dit is met ander woorde nie Jesus se 
geboorte wat volgens Paulus Jesus se 'Godseunskap' bepaal het nie. Dié het Jesus vớr sy geboorte uit 'n vrou besit. Paulus beklemtoon, net soos die Johannese skool, die anomalie, die paradoks, dat die ewige Seun van God by sy geboorte uit 'n vrou (vgl weer Job 14:1 en Matt 11:11) deelgekry het aan die lot van kortstondige lewe en besondere lyding. Hierdie voorstelling van 'Godseunskap' is onversoenbaar met dit wat met die konsep van 'n Goddelike geboorte uitgebeeld word (Pannenberg 1968:143).

In die lig van die uitsonderlike posisie wat Matteus en Lukas se Jesus-geboortevertellings in die Nuwe Testament inneem, is Bultmann (1968:133) se gevolgtrekking dus korrek wanneer hy opmerk dat die bepaalde verstaan van 'Godseunskap' wat onderliggend aan die vertelling oor die maagdelike geboorte lê, oorskadu (überflügelt) word deur die tipe verstaan van 'Godseunskap' waarvan Paulus en Johannes getuig. Paulus en Johannes, elkeen egter op 'n eie onderskeie manier, werk met die gedagte van 'aanneming tot kind van God'.

\section{SEUN VAN GOD EN PREËKSISTENSIE}

Die tipe interpretasie van Jesus as 'Seun van God' in die sinoptiese tradisie was die Gees-vervulde, wonderwerkende 'God-mens' figuur. Volgens die tweede tipe is Jesus Christus gesien as die preëksistente Seun van God wat mens geword het. Paulus, soos Johannes, gaan doodeenvoudig vanuit hierdie gedagte as aanname uit. Die voor-Pauliniese Christus-himne (Flp 2:6-11) toon ook aan dat Paulus nie die eerste persoon was wat hierdie gedagte in die Christelike denke ingevoer het nie. Dit is 'n pre-Christelike konsep wat aangetref word in geskrifte van Griekssprekende Israeliete, soos byvoorbeeld in die Gelykenisse van Henog (1 Hen 39:4vv; 70:4 - kyk Casey 1991:79-85) en in die 'liefdesroman', Josef en Aseneth, waarin Josef nie net 'seun van God' (JosAs $6: 3,5 ; 18: 11 ; 21: 4$ - kyk Chesnutt 1996:296) genoem word nie, maar ook 'eersge-

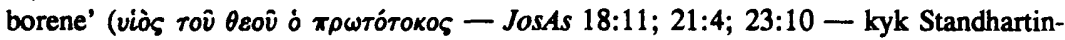
ger 1995:203; 1996:314).

Die siening dat die preëksistente Seun van God mens geword het, staan by Paulus nie los van die gemelde paradoks van die verlossingsgebeure nie. Die totale klem le in hierdie verband op die feit van die menslikheid en die menslike lot van die Seun van God wat mens geword het. Hierdie feit, soos duidelik betuig in Filippense 2:6-11, word egter teëgespreek deur die idee dat Jesus Homself gedurende sy (aardse) lewe deur middel van wonderwerke as God se Seun betoon het. Dit was daarom vir Paulus 'n vreemde gedagte om Jesus se optredes te sien as gevul met die mirakelagtige (Bultmann 1968:134). Tog is hierdie twee Christologieë in 'n ietwat gespanne verhouding in die Hellenistiese Christendom gekombineer. Die voorstelling van die Seun van God as wonderwerker het as gevolg van die getuienis in die sinoptiese evangelies bewaar gebly. Vir Ignatius (Ad Ephesios 19:1; vgl ook Ad Smyrnaeos 1;1) was die maagdelik- 
heid van Maria, haar bevalling en die dood van die Kurios 'drie misteries'. Aan die ander kant was dit juis Ignatius wat die paradoks van die preëksistente Christologie beklemtoon het.

Daar moet egter nog 'n derde tipe van die 'Seun van God'-figuur herken word (Bultmann 1968:134). Die Gnostiek se idee van 'goddelike seun' het dikwels nie alleen soteriologiese nie, maar ook kosmologiese betekenis gehad. Waarskynlik was die kosmologiese inderdaad die primêre betekenis wat onafhanklik in mitologieë en in godsdiensfilosofiese spekulasies soos dié van Filo ontwikkel het. By Filo is die kosmiese Logos die 'seun' van God. 'n Soortgelyke ontwikkeling word ook in die Hermetiese geskrifte aangetref (Bultmann 1968:134).

'n Parallelle verskynsel is die personifikasie van die 'Wysheid' as 'n kosmiese figuur wat ook in die wysheidsliteratuur van die Ou-Testament aangetref (vgl Spreuke 8:22-30) en voorwerp van spekulasie in die Judaïsme, veral by Griekssprekende Israeliete, geword het. Baie vroeg al het hierdie spekulasie oor die Logos en die Wysheid 'n pad binne-in die Hellenistiese Christendom gebaan (kyk o a Van Aarde 1996b:846). Vroeg in die vyftigerjare verwys Paulus reeds in 1 Korintiërs 8:6 na

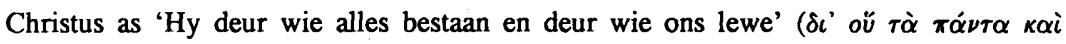
$\left.\dot{\eta} \mu \varepsilon \hat{\imath} \zeta i^{\prime} \alpha \dot{v} \tau o \hat{v}\right)$, 'n formule waarin die kosmologiese en die soteriologiese rolle van Christus gekombineer is (Bultmann 1968:134). Of dit Paulus was wat vir die eerste keer aan Christus 'n kosmiese rol as 'skeppingsmiddelaar' toegeskryf het, kan nie met sekerheid bepaal word nie. Die wyse hoe hy daaroor praat, skep die indruk van 'n algemeenheid en dit dui weer daarop dat, wat hierdie spreekwyse betref, Paulus nie alleen was nie. Die vanselfsprekendheid waarmee hy in 2 Korintiërs 4:4 Christus die 'beeld van God' ( $\varepsilon i \kappa \grave{\omega} \nu$ rov̂ $\theta \varepsilon \circ \hat{\text { ) }}$ noem, versterk hierdie indruk.

Ook die term 'beeld van God' is deel van die konteks van die kosmologiese Seunvan-God-spekulasie. Hierdie saak kom by Filo en in die Hermetiese en Gnostiese literatuur voor. Ná Paulus word hierdie kosmologiese betekenis van Christus veral in Kolossense 1:15-17 aangetref waar Christus voorgestel word as die 'die beeld van on-

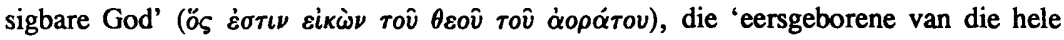

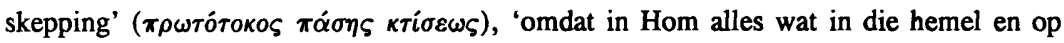

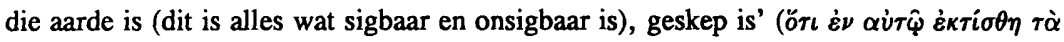

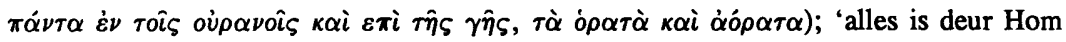

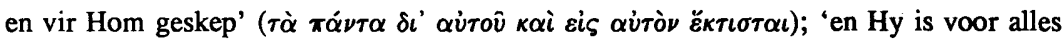

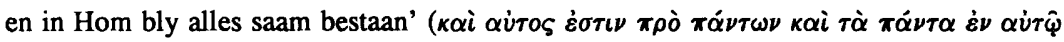

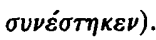

Bultmann (1968:135) wys daarop dat die skrywer van die Efesiërbrief ook hierdie spekulasie ken. Die skrywer van die Efesiërbrief het dit immers in die Kollossensebrief aangetref toe hy dié brief as bron gebruik het. In die Efesiërbrief $(1: 20-22)$ is die kosmologie in ekklesiologie verander, ' $n$ verandering wat reeds deur die skrywer van die 
Kollossensebrief (1:18a) geïnisieer is. Buiten die proloog van die Johannesevangelie is die Hebreërbrief getuienis daarvan dat ander naas Paulus en sy skool Christus gesien het as die Seun van God in die verskyning van 'n kosmiese figuur. Hebreërs 1:3 beskryf Christus as dié Een wat 'alle dinge deur sy magswoord in stand hou' ( $\phi \varepsilon \dot{\varepsilon} \rho \nu \tau \varepsilon$

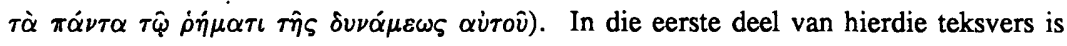

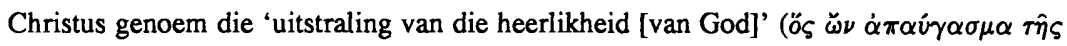

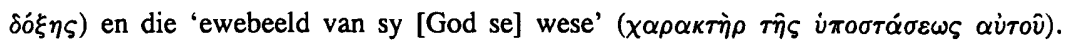
Laasgenoemde uitdrukking is niks anders nie as ' $n$ parafrase van die konsep 'beeld' $(\varepsilon i \kappa \omega \nu)$. Soortgelyk sê die Herder van Hermas (Sim IX 12, 2): 'Die Seun van God is ouer as God se hele skepping, met die gevolg dat Hy die Vader se raadgewer by die

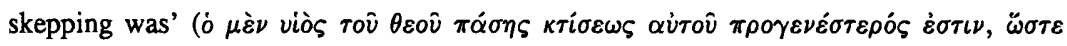

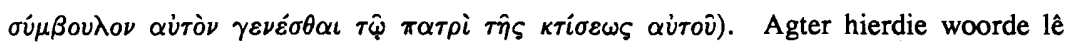
duidelik Spreuke 8:27vv ten grondslag. Dit is veral in Hermas (Sim IX 14, 5) waar die kosmologiese rol van die Seun van God uitdrukking vind: 'die naam van die Seun van God is groot en onbegryplik en onderhou die hele wêreld. Indien die hele skepping dan deur die Seun van God in stand gehou word ...?' Die antwoord wat gegee is op die vraag wat hier deur Hermas begin is, tref 'n ekklesiologiese gevolgtrekking vanuit die betrokke kosmologiese premisse.

\section{SAMEVATTING}

Ons kan die uiteensetting van die gebruik van die titel 'Seun van God' hierbo soos volg saamvat: Ten tye van die ontstaan van die Nuwe Testament is Griekssprekendes reeds vir 'n geruime tyd in die 'verbondsvolk' Israel, die 'volk van God', opgeneem. Wat die sosio-religieuse regte van hierdie proseliete was, is nie nou onmiddellik vir ons van belang nie. Wat vir die doeleindes van hierdie artikel belangrik is, is die feit dat die titel 'Seun van God' onder invloed van die Griekssprekende Israeliete 'n verandering in verwysing ondergaan het. Vroeër het die Israeliete hoofsaaklik na die ideale messiaanse koning met hierdie titel verwys. Die historiese Jesus het, wat sy verwysing na God as Koning in onlosmaaklike verband met God as Vader betref, nie 'n tipiese koninklike heerskappy in die oog' gehad nie, maar eerder 'n huishouding (kyk Van Aarde 1997a). Hierdie aangeleentheid val egter buite die gesigsveld van die onderhawige studie. Dit geld ook die verskil tussen die bedoeling van Jesus met die uitdrukking 'Abba' ('Pappa') en dié wat Nuwe Testament skrywers met die uitdrukking 'Seun van God' in die oog gehad het.

Die volgende uitspraak van Robert Funk vat die kompleksiteit van die verhouding tussen die historiese Jesus en die kerugmatiese Christus goed saam: 
The paradox of the dead god represents the marriage of the imageless tradition of Israel with the iconic mentality of the Graeco-Roman world. For descendents of Abraham, no one has ever seen God, and God cannot be pictured. For the Greeks, to consort with the gods was an everyday matter, and it was commonplace to make images of every imaginable deity. For hellenized Christians, Jesus the iconoclast became Christ the icon. Because Christianity has a twin heritage - its ancestors are both Jews and Greeks - it has never quite made up its mind whether it is iconic or iconoclast.

(Funk 1996:44)

Toegepas op die term 'Seun van God' het hierdie studie uitgewys dat dié voorstelling drie tipiese verwysings in die Grieks-Romeinse denke van die Grieke gehad het. Om met die derde te begin: Hierdie tipe het 'n kosmologiese verwysing gehad en kom in die Nuwe Testament in ' $n$ gemengde vorm met die tweede tipe voor. Binne die verwysingsraamwerk van die uitdrukking 'aanneming tot kind' (vioøeoi $\alpha$ ) is hierdie derde tipe wel ter sake, aangesien dit die konteks is waarin hierdie uitdrukking in die deuteroPauliniese Efesiërbrief (1:5) voorkom (kyk Schlier 1971b:52-54). Die onderhawige studie het egter as sodanig nie hierop gefokus nie, maar wel op die eerste twee tipes.

Die eerste tipe hou verband met die mitologiese idee van die verwekking van 'n kind op grond van die seksuele gemeenskap van 'n godheid met 'n sterflike mens. 'n

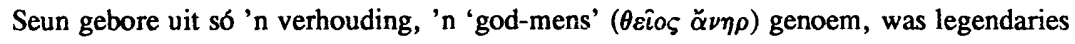
bekend vir sy weldade aan die mensheid bewys en is soms ook kulties vereer. Sommige van hierdie tradisies het die ma van die 'seun van God' as 'n maagd voorgestel, byvoorbeeld Perseus, gebore uit die maagd Danae by Zeus, en sommige het geen klem op die maagdskap al dan nie van die vrou gelê nie, byvoorbeeld Hercules uit Alkmena by Jupiter. Die klem het gelê op die weldade van die 'seun van God'. Die interpretasie van die Ou-Testamentiese verhale oor Moses en die profete is in die Griekse periode deur hierdie motief beïnvloed. Teen die agtergrond van die rol wat intermediêre figure, soos engele en die Gees van God, in hierdie periode gespeel het, is die 'Godsmanne' in die Israelitiese tradisie voorgestel as vervul met die Gees van God, 'n vervulling wat óf by geboorte plaasgevind het of by die 'aanneming tot seun van God' wat nie noodwendig voorgestel is as iets wat by geboorte plaasgevind het nie.

Paulus, wat die eerste literêre getuie in die Nuwe Testament is, neem nie die tradisie van Jesus as 'wonderdoenende Seun van God' op nie. In die lig van wat Paulus in Filippense 2:7-8 en 2 Korintiërs 8:9 oor die pre-eksistente se selfvernedering sê, kan ons aanvaar dat Paulus nie die wondervertellings oor Jesus as versoenbaar met sy 
(Paulus se) evangelie beskou het nie. Die wondervertellings stel Jesus voor as iemand wat Goddelike krag of mag gehad het, terwyl Jesus se optredes, volgens Paulus, nie gekenmerk is deur mag nie, maar deur swakheid en kwesbaarheid - selfs tot in die dood aan die kruis. Dit lyk asof Paulus in die Christus-himne van Filippense 2 in terme van die rolverwagtings van die lede van 'n huishouding redeneer: As die preeksistente, 'eniggebore' Seun van God het Jesus Vadergelyke 'status' wat juridies veral in die erfreg te sien is. Hoewel Jesus se diensgestalte voldoen aan die rolverwagting van 'n seun in verhouding tot sy vader, is dit egter nie die geval ten opsigte van gehoorsaamheid deur middel van lyding en selfs die dood nie; Jesus se 'voorbeeldigheid' as Seun van God kom derhalwe vorendag in die tipe gehoorsaamheid waartoe Hy tot in die dood - die dood aan die kruis -- bereid was en dit word juridies deur Paulus beskryf in terme van 'n prysgawe van vadergelyke status en die rolvervulling van 'n slaaf in die huishouding.

Net soos Seneca die apotheosis-motief met die opstanding uit die dood in verband bring (kyk Van Aarde 1997c), manifesteer Jesus se 'Godseunskap', volgens Paulus, in die opstandingsgebeure en in Romeine 1:3-4 bring hy dit met die aannemingsmotief in verband. Hier beskryf Paulus Jesus se 'aanneming' tot (oftewel 'verklaring as' [o $\rho \iota \zeta \omega]$ ) Seun van God in terme van die antinomie gees-vlees. Anders as die gangbare kerklike tradisie, soos dit onder andere in die Afrikaanse Bybelvertaling van 1993 vorendag kom, moet die uitdrukking 'volgens die gees van heiligheid' ( $\kappa \alpha \tau \grave{\alpha} \pi \nu \varepsilon v \hat{v} \mu \alpha \dot{\alpha} \gamma \iota \omega \sigma v ́ \nu \eta \varsigma)$ in Romeine 1:4 gesien word as die dialektiese (versweë) teenpool van die uitdrukking

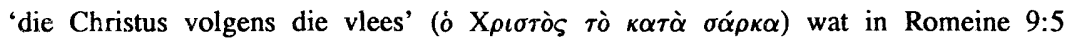
voorkom.

In die Nuwe Testament is Markus die tweede literêre getuie, kronologies gesien, wat van 'n 'aanneming tot Seun van God' op grond van die werk van die Gees van God in die lewe van Jesus getuig. Ook Markus koppel dit nie aan 'n Goddelike geboorte nie, maar aan die doop van Jesus, dit wil sê aan die begin van Jesus se Geesvervulde aktiwiteit as 'wonderwerker'. Lukas, wat Markus as bron ken, neem die tradisie van Geesvervuldheid wat by Jesus se doop plaasvind oor, maar sien Jesus se 'aanneming tot Seun van God' reeds geantisipeer in Jesus se 'maagdelike verwekking' op grond van die werk van die Gees van God. Die goddelike geboortes in die mitologiese godeverhale en keiserkultus vorm die agtergrond waarteen Lukas as gesofistikeerde Griek Jesus se geboorte (en hemelvaart) in die lig van die Hellenisties geïnterpreteerde OuTestamentiese tradisies oor 'Godsmanne' weergee. Matteus, kronologies die derde literêre getuie binne die sinoptiese tradisie, koppel die Geesvervuldheid van Jesus, net soos by Lukas, aan Jesus se rol as Messias en as apokaliptiese Menseseun. By implikasie is Matteus $(1: 16 ; 3: 9)$ duidelik daaroor dat Jesus nie van nature 'n 'kind van 
Abraham' is nie, maar as die eind-tydelike, vindiserende Messias/Menseseun, is Jesus volgens Matteus by geboorte opgeneem in die (nuut, hergedefinieerde) verbondsvolk. Om tot die verbondsvolk te behoort is om 'kind van Abraham' te wees, en om 'kind van Abraham' te wees is om 'kind van God' te wees. Hierdie 'aanneming tot Seun van God' koppel Matteus aan die motief van die heilige huwelik (vgl Horsley 1979:30-54) wat Josef op grond van 'n Goddelike intervensie met die 'onrein' swanger Maria sluit. 'n Soortgelyke motief vind ons in die Ou-Testamentiese pseudepigrafiese geskrif, Josef en Aseneth (21:4 - soos gerekonstrueer as die sogenoemde 'langer versie' deur Christoph Burchard 1965 — kyk Standhartinger 1996:304, 310-314; 1995:137).

Johannes staan buite die sinoptiese tradisie en verteenwoordig soos Paulus die tweede tipe. Hierdie tipe 'Godseunskap' wat in die Nuwe Testament neerslag gevind het, lê klem op 'n anomalie, 'n paradoks. Hier word van die aanname uitgegaan dat 'n preëksistente figuur, gelyk in status met God (vgl Joh 1:1-2), die lot van menslikheid volledig op Hom geneem het. 'n Gewone natuurlike geboorte is 'n manier waarop hierdie volledige deelkry aan menslikheid voorgestel is (vgl Gal 4:4 en Joh 1:14). In die Johannesevangelie $(3: 5-6 ; 7-8)$ sien die broers van Jesus en omstanders vir Jesus volledig as iemand vanuit Galilea. Sowel Paulus as Johannes verkondig wat vir mense paradoksaal aanstootlik is, naamlik dat die preëksistente Seun van God in die gestalte van nietige mensheid gebore is en ook só sterf. In hierdie skynbare anomalie lê egter die Goddelike verlossingsgebeure verskuil. Johannes beeld hierdie verlossing uit in die spanning dat mense wat van nature gebore is, op grond van hulle deelkry aan Jesus as die eniggebore Seun van God, ook 'n geboorte vanuit die Gees van God deelagtig geword het, en derhalwe kinders van God genoem word. Dieselfde gedagte kom min of meer ook by Paulus voor. Wat Paulus betref, word mense op grond van hulle deelkry aan die lot en lyding van die preëksistente Seun van God tot kinders van God

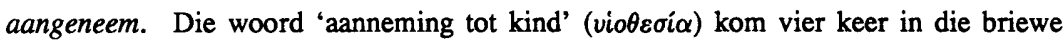
van Paulus voor, te wete Romeine 8:15; 8:23; 9:4 en Galasiërs 4:5. Wat die Nuwe Testament as geheel betref, is daar buiten die gemelde vier voorkomste nog net een ander geval en dit is in die deutero-Pauliniese Efesiërbrief (1:5). In die Romeinebrief (kyk Van Aarde 1997b) gebruik Paulus die onderhawige uitdrukking teen die agtergrond van sy argument dat die 'huis van Israel' in afwagting was dat God sy beloftes sal vervul (kyk Atkins 1991:172). Dit gaan by Paulus om 'n nuwe Israel, om mense wat nie noodwendig as gevolg van bloedverwantskap onder die 'kinders van Abraham' tel nie, maar wel deur God as sodanig aangeneem is. 


\section{Literatuurverwysings}

Aland, B, Aland, K, Karavidopolos, J, Martini, C M \& Metzger, B (ed) [1966] 1994.

The Greek New Testament. Fourth revised edition, in cooperation with the Institute for New Testament Textual Research, Münster/Westphalia. Stuttgart: Deutsche Bibelgesellschaft.

Allison, D C 1993. The new Moses: A Matthean typology. Minneapolis: Fortress.

Atkins, R A 1991. Egalitarian community: Ethnography and exegesis, with a foreword by Mary Douglas. Tuscaloosa: The University of Alabama Press.

Berkowitz, L \& Squitier, K A [1977] 1986. Thesaurus Linguae Graecae: Canon of Greek authors and works. Second edition. New York: Oxford University Press.

Betz, H D 1968. Jesus as divine man, in Trotter, F T (ed), Jesus and the historian, 114-133. Philadelphia: Westminister Press.

Bonechi (Casa Editrice) 1995. Art and history of Pompeii: With the reconstructions of the city. English edition. Florence: Centro Stampa Editoriale Bonechi.

Brown, R E 1973. The virginal conception \& bodily resurrection of Jesus. New York: Paulist Press.

1979. The birth of the Messiah: A commentary on the infancy narratives in Matthew and Luke. New York: Doubleday.

Bultmann, R [1951] 1952. Das christologische Bekenntnis des Ökumenischen Rates, in Glauben und Verstehen: Gesammelte Aufsätze, Zweiter Band, 246-261. Tübingen: Mohr.

[1958] 1968. Theologie des Neuen Testaments. 6., durchgesehene Auflage. Tübingen: J C B Mohr (Paul Siebeck). (Neue Theologische Grundrisse.)

Burchard, C 1965. Untersuchungen zu Joseph und Aseneth: Überlieferung-Ortbestimmung. Tübingen: Mohr. (WUNT 8.)

Byrne, B 1979. 'Sons of God' - 'Seed of Abraham'. Rome: Biblical Institute Press. (Analecta Biblica 83.)

Casey, M 1991. From Jewish prophet to gentile god: The origins and development of New Testament Christology. Cambridge: James Clarke \& Co.

Chesnutt, R D 1996. From text to context: The social matrix of Joseph and Aseneth, in Society of Biblical Literature 1996 Seminar Papers, 285-302. Atlanta: Scholars Press.

Crossan, J D 1994. The infancy and youth of the Messiah, in Shanks, H (ed), The search for Jesus: Modern scholarship looks at the Gospels, 59-81. Washington, DC: Biblical Archaeological Society.

1996. Who is Jesus? Answers to your questions about the historical Jesus, with Watts, R G. New York: Harper Collins Publishers. (Harper Paperbacks.)

David, M 1955. Adoptie in het oude Israël. Mededelingen Kon. Ned. Akademie, afd. Letterkunde, Nieuwe Reeks XVIII, nr. 4. 
Daube, D 1957. Evangelisten und Rabbinen. ZNW 48, 119-120.

Deißmann, A [1927] 1965. Light from the ancient east. English translation reprinted. Grand Rapids: Baker Book House.

Derrett, J D M 1973. Jesus's audience: The social and psychological environment in which he worked. New York: The Seabury Press. (A Crossroad Book.)

De Waard, J \& Nida, E A 1973. A translator's handbook on the book of Ruth. London: United Bible Societies. (Helps for Translators XV.)

Dibelius, M 1932. Jungfrauensohn und Krippenkind: Untersuchungen zur Geburtgeschichte Jesu im Lukas-Evangelium. Heidelberg: Carl Winters Universitätsbuchhandlung.

Dittenberger, W 1960. Sylloge Inscriptionum Graecarum, Volume 2. 4th Edition. Hildesheim: Olms.

Eichrodt, W 1970. Ezekiel: A commentary, tr by C Quin. London: SCM Press. (The Old Testament Library.)

Elliott, J H 1994. The evil eye and the Sermon on the Mount: Contours of a pervasive belief in social scientific perspective. Biblical Interpretation 2/1, 51-84.

Funk, R W 1996. Honest to Jesus: Jesus for a new millennium. San Francisco: Harper Collins Publishers.

Funk, R W \& Hoover, R W [1993] 1997. The Five Gospels - What did Jesus really say? The search for the authentic words of Jesus. San Francisco: Harper Collins Publishers.

Grenfell, B P, Hunt, A S \& Bell (ed) 1898-1927. The Oxyrhynchus Papyri. 17 Volumes. London: Egypt Exploration Fund.

Hahn, F 1974. Christologische Hoheitstitel: Ihre Geschichte im Fruhen Christentum. 4.Auflage. Göttingen: Vandenhoeck \& Ruprecht.

Harris, M J 1992. Jesus as God: The New Testament use of Theos in reference to Jesus. Grand Rapids, MI: Baker Book House.

Hengel, M 1976. The son of God: The origin of christology and the history of JewishHellenistic religion, tr by J Bowden. Philadelphia: Fortress Press.

Horsley, R A 1979. Spiritual marriage with Sophia. Vigiliae Christianae 33, 30-54.

Koekemoer, P J T 1958. Die dogma van die parthenogenesis en sy betekenis in die Reformatoriese en Roomskatolieke dogmatiek. DD-proefskrif, Universiteit van Pretoria.

Koester, H 1971. One Jesus and four primitive gospels, in Robinsin, J M \& Koester, H (ed), Trajectories through early Christianity, 158-204. Philadelphia: Fortress Press.

Liddell, H G \& Scott R [1940] 1961. A Greek-English lexicon. A New Edition. Revised and augmented throughout by $\mathrm{H}$ S Jones. London: Oxford University Press. 
Louw, J P \& E A 1988. Greek-English lexicon of the New Testament based on semmantic domains, Volume I: Introduction \& domains. New York: United Bible Societies.

Maulucci, F P 1996. The National Archaeological Museum of Naples. Naples: Publisher Carcavallo.

Oepke, A 1973. Der Brief des Paulus an die Galater. Bearbeitet von J Rohde. Berlin: Evangelische Verlaganstalt. (Theologischer Handkommentar zum neuen Testament.)

Overman, J A 1990. Matthew's gospel and formative Judaism: The social world of the Matthean community. Minneapolis: Fortress Press.

Pannenberg, W [1964] 1968. Jesus-God and man, tr by L L Wilkins \& D A Priebe. London: SCM Press.

Pilonenko, M 1968. Joseph et Aséneth: Introduction, texte critique en notes. Leiden: Brill. (SPB 13.)

Porkomy, P 1971. Der Gottessohn: Literarische Übersicht und Fragestellung. Zürich: Theologische Verlag.

Rahlfs, A (ed) [1935] 1971. Septuaginta. Id est Vetus Testamentum graece iuxta LXX interpres. Editio Nona. Stuttgart: Würtembergische Bibelanstalt.

Richardson, N 1979. Was Jesus divine?. London: Epworth Press.

Saldarini, A J 1994. Matthew's Christian-Jewish community. Chicago: The University of Chicago Press. (Chicago Studies in the History of Judaism.)

Sand, A 1974. Das Gezetz und die Propheten: Untersuchungen zur Theologie des Evangeliums nach Matthäus. Regensburg: Pustet.

Schlier, H [1949] 1971a. Der Brief an die Galater. 5.Auflage der Neubearbeitung. Göttingen: Vandenhoeck \& Ruprecht. (Kritisch-Exegetischer Kommentar.)

- [1957] 1971b. Der Brief an die Epheser: Ein Kommentar. Düsseldorf: Patmos-Verlag.

Schmithals, W 1980. Das Evangelium nach Lukas. Zürich: Theologischer Verlag. (Zürcher Bibelkommentare.)

Smith, W R 1885. Kinship and marriage in early Arabia. Cambridge: Cambridge University Press.

Standartinger, A 1995. Das Frauenbild im Judentum der hellenistischen Zeit: Ein Beitrag anhand von 'Joseph \& Aseneth'. Leiden: Brill. (Arbeiten zur Geschichte des Antiken Judentums und des Urchristentums.)

1996. From fictional text to socio-historical context: Some considerations from a textcritical perspective on Joseph and Aseneth, in Society of Biblical Literature 1996 Seminar Papers, 303-318. Atlanta: Scholars Press. 
Stanton, G N 1992. A gospel for a new people: Studies in Matthew. Edinburgh: T\&T Clark.

Taylor, L R [1931] 1981. The divinity of the Roman emperor. Reprinted. Chico, CA: Scholars Press.

Van Aarde, A G 1994a. God-with-us: The dominant perspective in Matthew's story, and other essays. Pretoria: University of Pretoria. (HTS Suppl 5.)

1995. The 'third quest' for the historical Jesus - where should it begin: With Jesus' relationship to the Baptiser, or with the nativity traditions? Neotestamentica 29/2, 325-356.

1996a. Die historiese ondersoek na Jesus van Nasaret in perspektief. HTS $52 / 2 \& 3,476-500$.

1996b. Kultuurkritiek, eerste-eeuse kulturele wysheid en die alternatiewe visie van Jesus van Nasaret. HTS 52/4, 833-849.

1997. Social identity, status envy and Jesus' Abba. Pastoral Psychology 45/6, 451-472.

1997b. Side-notes from Graeco-Roman and Hellenistic-Semitic literature to the

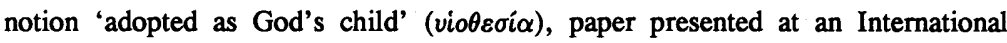
Conference of the South African Association for Patristic and Byzantine Studies at the University of Pretoria, August 27-29, 1997. (Forthcoming in Acta Patristica et Byzantina.)

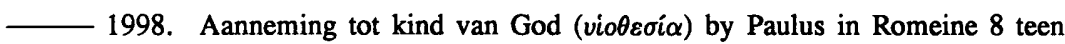
die agtergrond van die Jerusalemse tempelkultus. Skrif en Kerk 19/1. (Beplan om in Mei 1998 te verskyn.)

Weeden, T J 1971. Mark: Traditions in conflict. Philadelphia: Fortress Press.

Wevers, J W 1969. Ezekiel. London: Thomas Nelson and Sons Ltd. (The Century Bible New Series.)

Widengren, G 1969. Religionsphänomenologie. Berlin: De Gruyter. 